\title{
IS RAFFLESIA AN ANGIOSPERM?
}

\author{
Ng FSP
}

Forest Research Institute Malaysia, Kepong, Selangor, Malaysia; tropicalplantman@gmail.com

Submitted April 2019; accepted July 2019

\begin{abstract}
The taxonomic relationship of Rafflesia to other angiosperms has always been problematical. Its gynoecium bears no trace of anything that is recognisable as a carpel. In the absence of carpels, Rafflesia has no pistil and therefore no ovary in the angiosperm sense. Without an ovary, Rafflesia does not develop an angiosperm fruit. The seed is also different from angiosperm seeds, and the androecium bears no resemblance to an angiosperm androecium. Nearly all the morphological features of Rafflesia are not homologous with the corresponding features in angiosperms.
\end{abstract}

Keywords: Flowering plants, morphology, carpels, homology, host-parasite interaction

\section{INTRODUCTION}

The theoretical foundations of taxonomy are based the concept of homology. Homologous structures, even if they perform different functions, are considered to be derived from a shared design. In contrast, analogous structures, even if they perform similar functions, are derived from different designs. Hence the wings of birds are closely homologous with each other regardless of whether they fly and distantly homologous with the wings of bats because they share the same skeletal plan, but analogous with the wings of butterflies. Homology implies shared lineage while analogy implies different lineages. A summary of plant morphology and homology is presented here to support the argument that practically all of the features in Rafflesia assumed to be homologous with the corresponding features in angiosperms are not homologous at all, and that the Rafflesia developmental algorithm is fundamentally different from the developmental algorithm of angiosperms.

The foundation theory of plant morphology is Goethe's theory, published in a philosophical essay in 1790, that the appendages of the stem are homologous with each other (Goethe 1790). These homologous appendages include cotyledons, scale leaves, foliage leaves, bracts, sepals, petals, stamens and carpels, here referred to collectively as leaf homologs. Leaf homologs share a number of design features. They are (1) lateral outgrowths of the stem, produced in acropetal sequence, i.e. youngest is at the stem apex and oldest at the base, (2) bifacial, with adaxial and abaxial surfaces and (3) determinate in growth, meaning that each structure has a relatively fixed size, shape and life span, autodetaching or detachable from the stem at the end of its life.

In contrast, the stem is a central, linear (nonbifacial) structure, indeterminate in growth that bears leaf homologs laterally. The root is the downward extension of the stem and it does not bear leaf homologs. The combination of a stem and its leaf homologs is a shoot. The flower is interpreted as a shoot specialised for reproduction, made up of bracts, sepals, petals, stamens and carpels.

The concept of the stamen as a leaf homolog supports the interpretation of its pollen-bearing structure (anther) as a container formed by the folding of its blade and fusion at the blade margins. The ovule-bearing structure (ovary) is interpreted as a container formed by one or more carpels folded and merged at the carpel margins. The tips of the carpels serve as stigmas. The internal division of the ovary into locules is a consequence of the number and manner of fusion of the carpels. The sepals, petals, stamens and carpels follow each other in strict sequence and although we may choose to combine sepals and petals into a perianth, the perianth always originates before the anthers and the anthers before the carpels. The carpels occupy the apex. The gynoecium, made up of carpels, is therefore primarily superior in position. It only becomes inferior secondarily if the stamens and perianth, 
initiated below the carpels, grow, overtop and merge basally with the carpels, leaving the stigma free at the apex.

\section{MATERIALS AND METHODS}

This study was carried out on a series of fresh materials of Rafflesia cantleyi at various stages of development, obtained from upper Perak, Malaysia. Specimens were dissected, examined with microscopes, and documented by photographs. Interpretation is based on morphological theory as explained in the introduction above.

\section{RESULTS}

\section{The shoot system}

When Robert Brown described Rafflesia in 1821, he classified it as an angiosperm and a dicot because of its flower that bears five perianth lobes (Figure 1). The flower also bears a characteristic dome-shaped corona with an aperture on top. The perianth lobes and corona are united basally into a perianth tube (Figure 2). The perianth arises around a central axis which is the stem of the flower. The apex of the central axis is expanded into a disk and the narrowed part below the disk may be called a neck. The upper surface of the disk bears a number of finger-like projections known as processes. The overhanging part of the disk is called the rim. On the underside of the rim are the stamens and stigma.

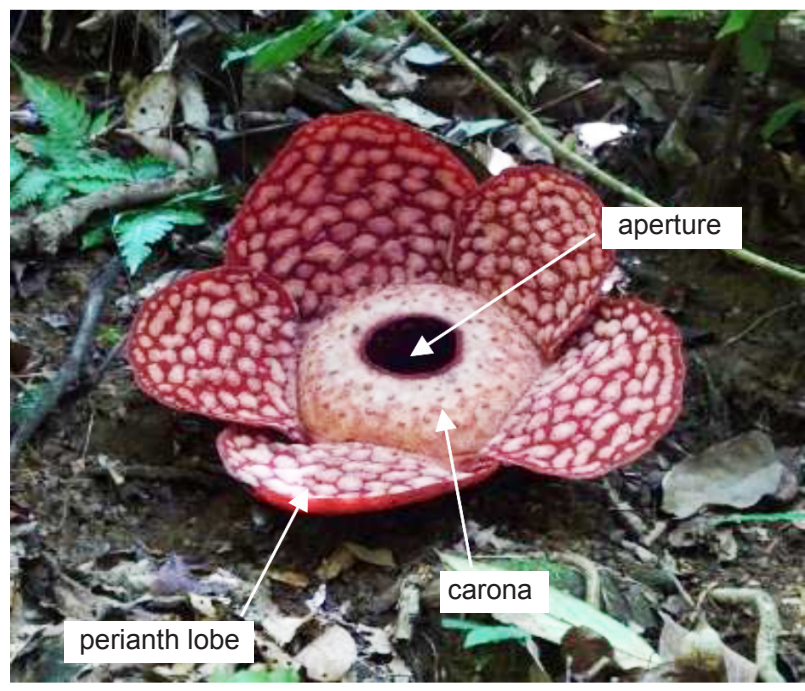

Figure 1 Flower of Rafflesia cantleyi

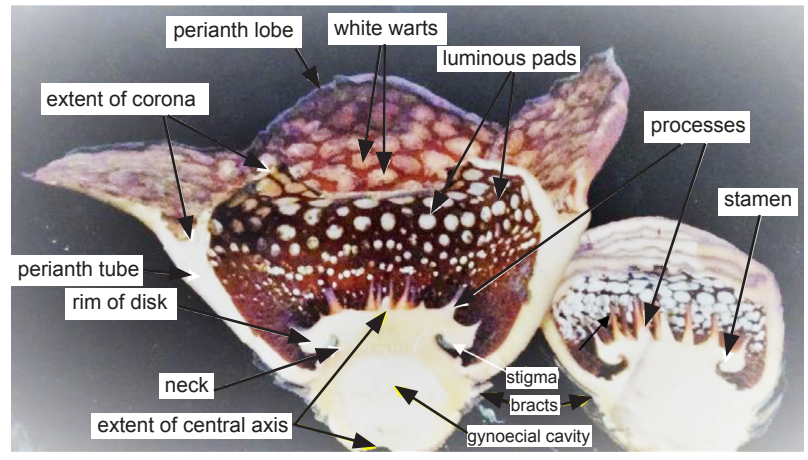

Figure 2 Longitudinal section (1.s.) of female flower (left) and male flower bud (right)

At the base of the flower are a number of overlapping bracts. In Rafflesia there are 23 bracts, initially leafy and forming a tight fleshy cabbage around the flower bud, eventually becoming dry and brittle. Hence, the 'flower bud' of Rafflesia may be described as a shoot ball consisting of 23 leafy bracts and a terminal flower bud.

The first sign of Rafflesia shoot emergence is when a corky subglobose outgrowth appears on the surface of the root or stem of the host Tetrastigma plant. The corkiness is superficial; the inside is fleshy and differentiated into an embryonic shoot complete with central axis, corona, perianth lobes and bracts. The entire shoot system is initiated simultaneously (Figure 3 ). The top of central axis is occupied by the disk, which is flat because the processes are not yet formed but the number of bracts is fixed at the start (Figure 4). Hence the developmental architecture of Rafflesia is closed or determinate rather than open and indeterminate.

The shoot develops and enlarges until the flower bud emerges through the bracts, enclosed by its perianth lobes. After reaching its maximum diameter, the bud is ready for anthesis. The perianth lobes open out to display a flower that is about three times as wide as the maximum bud. Hence a $15 \mathrm{~cm}$ bud would open into a flower of about $45 \mathrm{~cm}$ diameter.

\section{The flower}

Brown ran into difficulties when he tried to relate the structure of the stamens and pistils of Rafflesia to angiosperm models. In an amazing footnote to his 1834 paper, he wrote, 'In conclusion, therefore, it may perhaps be said that Rafflesia, in the structure both of ovarium and antherae, is not obviously reconcilable to any hypothesis 


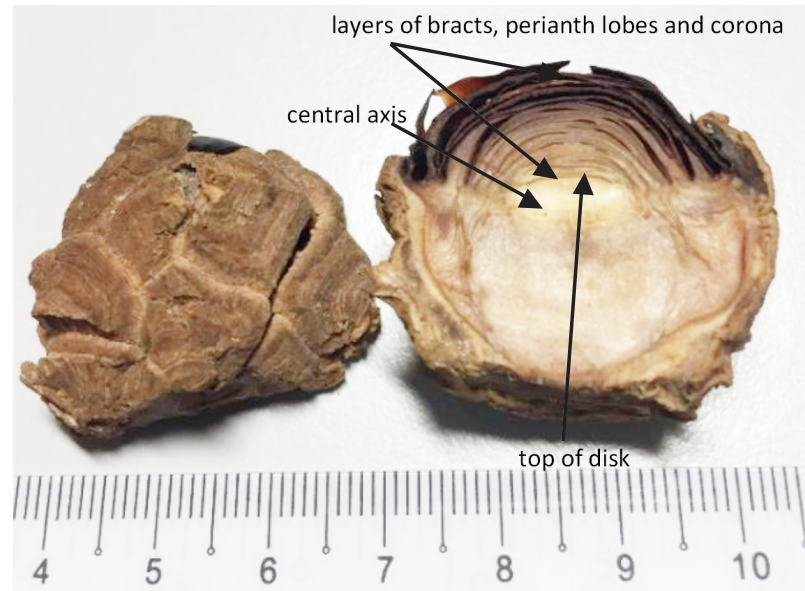

Figure 3 Left: the embryonic Rafflesia shoot as a corky outgrowth; right: l.s. section of the corky outgrowth

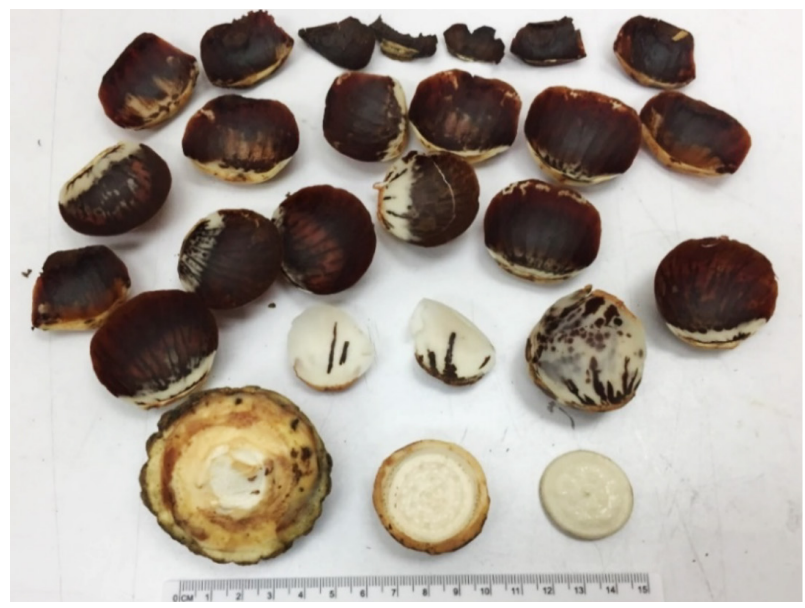

Figure 4 Dissected shoot ball of $6 \mathrm{~cm}$ diameter; upper rows show the 23 bracts; bottom row from left to right: base of the shoot ball, underside of the unexpanded perianth and upper surface of disk showing tiny lumps that will develop into processes

hitherto proposed to account either for the origin or for a common type of the sexual organ of phanerogamous plants' (Brown 1834). Brown thought that the processes were styles and expected the stigmas to be located at the apices of the styles as in any normal angiosperm. However, the processes in Rafflesia are not styles because they are developed in both male and female flowers and do not behave like styles. The location and form of the stigmas remained unknown until identified by Solms-Laubach (1876) as an annular band of tissue on the underside of the rim of the disk (Figures 5-7). Confirmation was provided by Koorders (1918) who found a germinated pollen grain on such a band of tissue in $R$. zollingeriana.

In the male flowers the stigmatic band is absent and instead, a circle of dome-shaped anthers occupies the underside of the rim of the disk (Figure 5). Banziger (1991) described how a fly visiting the underside of the rim of a male flower would brush against the stamens and come away with a blob of pollen on its back. Then on visiting the rim of the female flower, the pollen would be brushed onto the stigmatic surface. It took a long time for the stigma to be located and explained because the stigmas were not where they were supposed to be, i.e. at the tips of the carpels but there are no carpels. Brown did not suspect that there are no carpels in Rafflesia. The absence of carpels was confirmed in 2014 by Nikolov et al. who declared, after detailed study of floral meristem initiation, that carpels are absent and 'the Rafflesiaceae have evolved an alternative form of gynoecium development that has no equivalent in other angiosperms' (Nikolov et al. 2014).

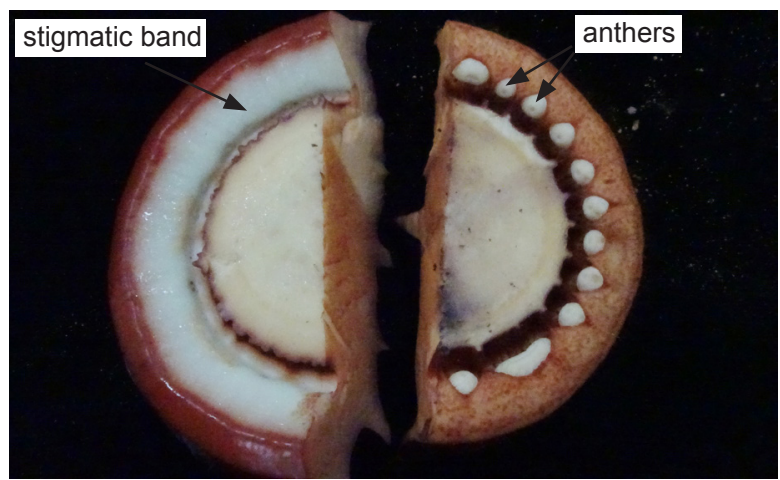

Figure 5 Underside of the rims of female and male flowers to show stigmatic band (left) and circle of anthers (right)

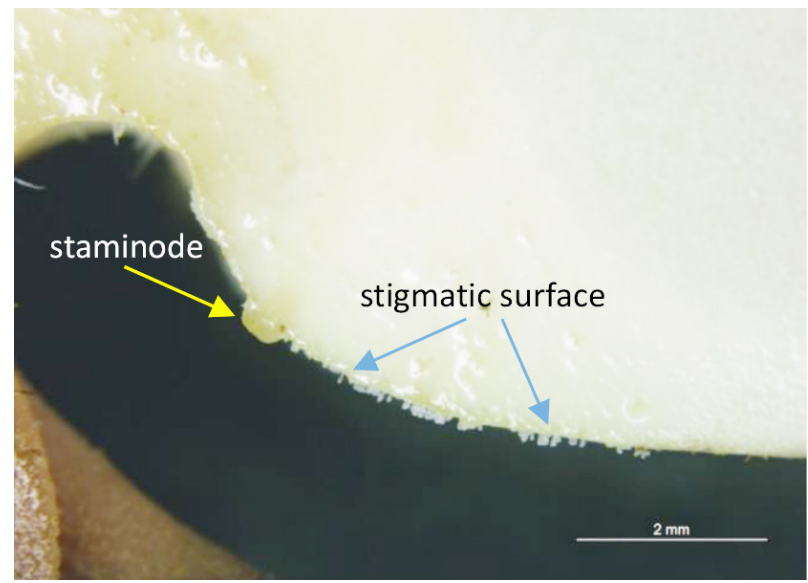

Figure 6 Section of rim of female flower showing a staminode and stigmatic surface 


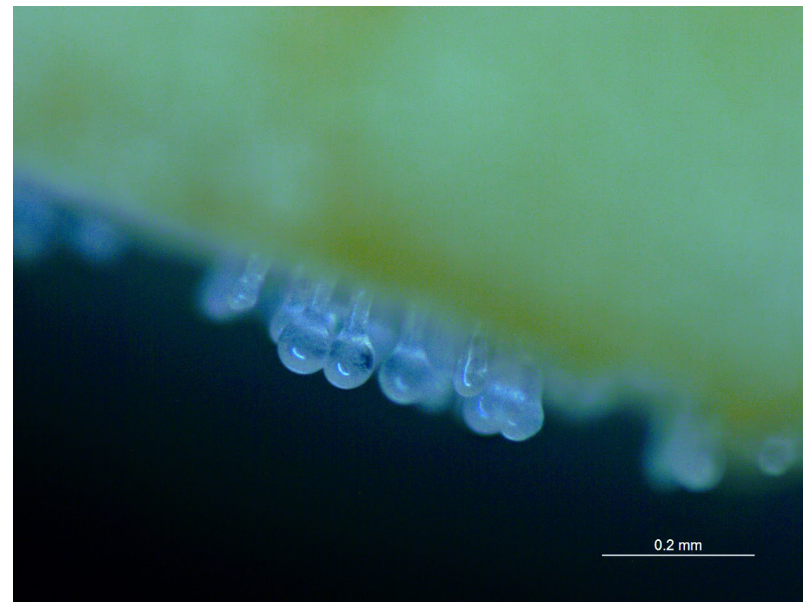

Figure 7 Papillae on stigmatic surface

\section{The gynoecium}

In addition to his inability to locate the stigma, Brown had difficulty deciding on the position of the ovary, vacillating between superior and inferior in his first paper in 1821, then opting for superior in his second paper in 1834 . He was also baffled by the internal geography of the ovary. His comments in the latter were 'The transverse section of the ovarium presenting an indefinite number of cavities irregular in form, having no apparent order, and over the whole of whose surfaces the ovula are inserted, is hardly reconcilable to the generally received type of the female organ; and as these cavities exist to the same extent and with similar irregularity from centre to circumference they may with equal probability be considered as originating from the axis or from the parietes of the ovarium' (Brown 1834). Meijer (1997), who had probably examined more species than anyone else for his Flora Malesiana revision, ignored Brown's misgivings and described the ovary simply as 1-locular with numerous placentae. However, without carpels, there can be no ovary in the angiosperm sense, no basis for describing locules and placentation and no basis for determining whether the ovary is superior or inferior.

Instead of an angiosperm ovary, there is a gynoecial cavity developed within the central axis of the flower and this cavity is best described as a labyrinth of interconnected spaces between tightly spaced anastomosing vertical placental partitions in which all the surfaces are ovulebearing. The gynoecial cavity in Rafflesia cannot be homologous with an angiosperm ovary and cannot be described using angiosperm terminology. The maximisation of placental surfaces enables the flower to bear hundreds of thousands of ovules (Figures 8-11).

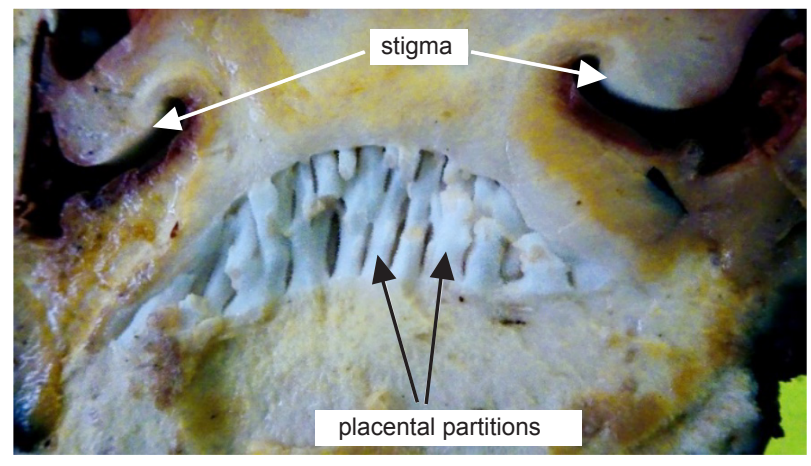

Figure 8 Female flower bud in 1.s. showing the gynoecial cavity with placental partitions

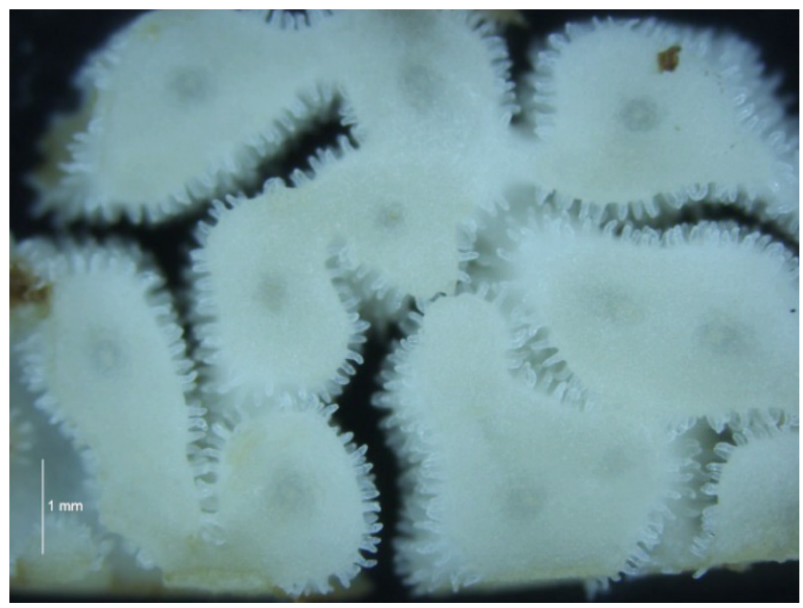

Figure 9 Transverse section (t.s.) of placental partitions showing vascular tissues and young ovules

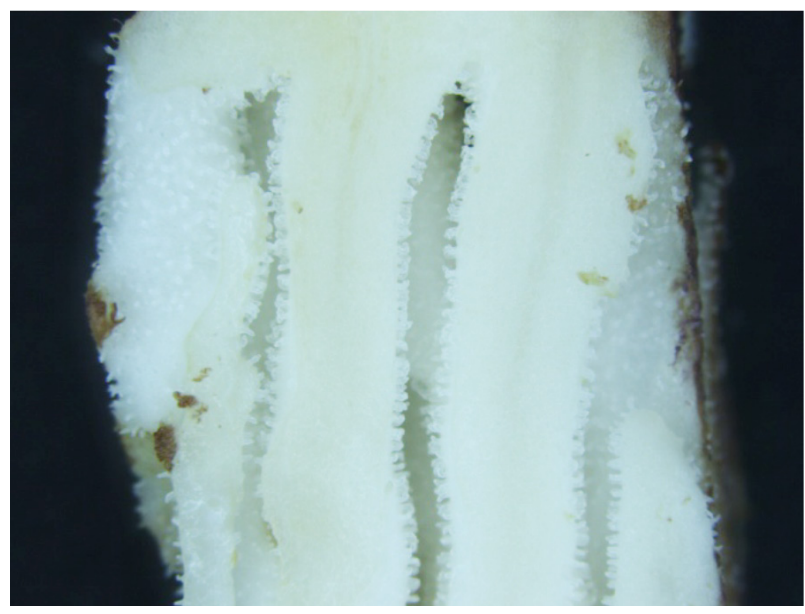

Figure 10 Vertical section of placental partitions 


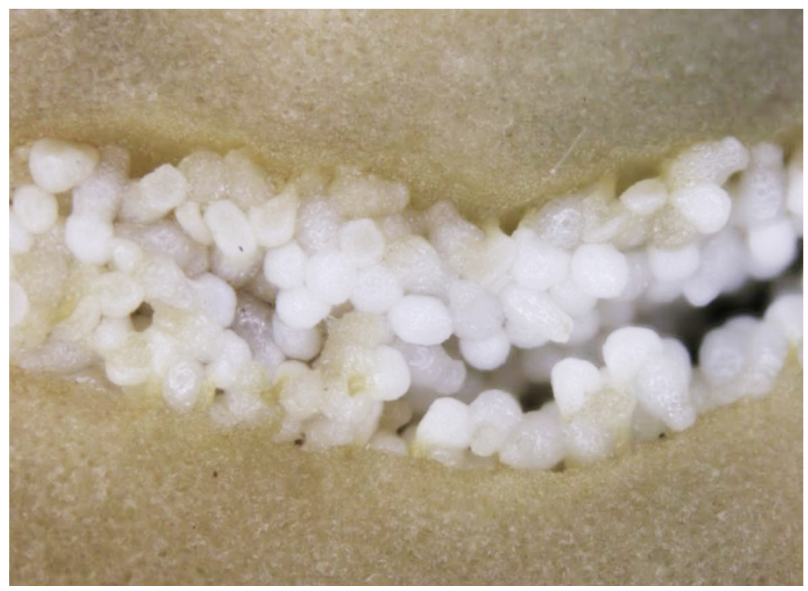

Figure 11 Ovules filling the space between placental partitions

\section{The fruit}

Without an angiosperm carpellate ovary, Rafflesia does not produce an angiosperm carpellate fruit. Brown (1821) included this passage from a letter by William Jack, 'The flower rots away not long after expansion and the seeds are mixed with the pulpy mass.'Jack did not see any structure that he could recognise as a fruit.

What happens is that about five days after anthesis, the flower fades, collapses and begins to decay. In the male, the flower rots away but in the female, a layer of remnant tissue is left to act as the fruit wall (Figures 12 and 13). The outer surface of this wall is dead tissue that develops an irregular pattern of cracks or fissures. On the forest floor, the fruit is inconspicuous among the knobs of surface roots, pieces of dead wood, and litter of dried leaves and twigs. There are no external indications to show when a fruit is ripe.

The external size of the fruit is fixed by the size of the central axis of the flower at anthesis (Figure 14). The gynoecial cavity enlarges internally as the fruit matures by thinning the fruit wall at its base. Eventually the wall breaks up and the seeds are exposed, embedded in soft white placental pulp. In the Rafflesia Centre in Poring, Sabah, squirrels and tree shrews have been observed to make holes in the fruit and nibble at the white pulp in which the seeds are embedded.

\section{The ovule and the seed}

The ovule is constricted in its middle into two lobes-a basal rounded lobe and a distal pearshaped lobe (Figure 15). The basal lobe, which

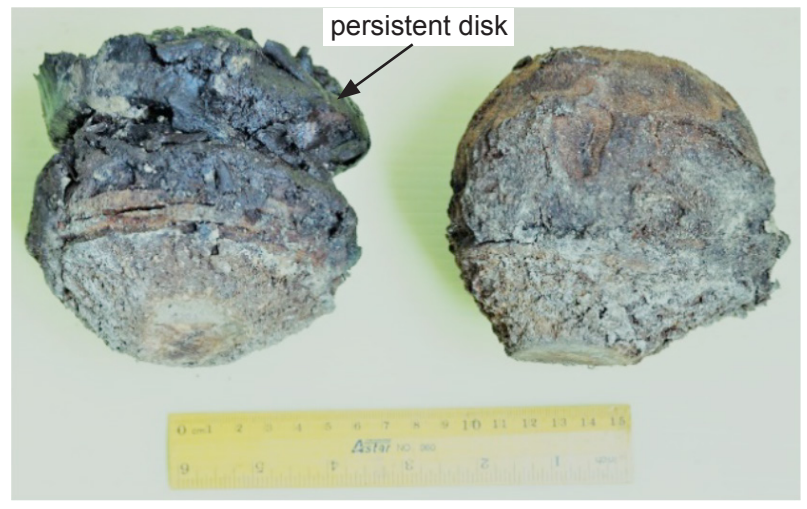

Figure 12 Left: young fruit with remnants of disk persisting; right: older fruit with disk worn down

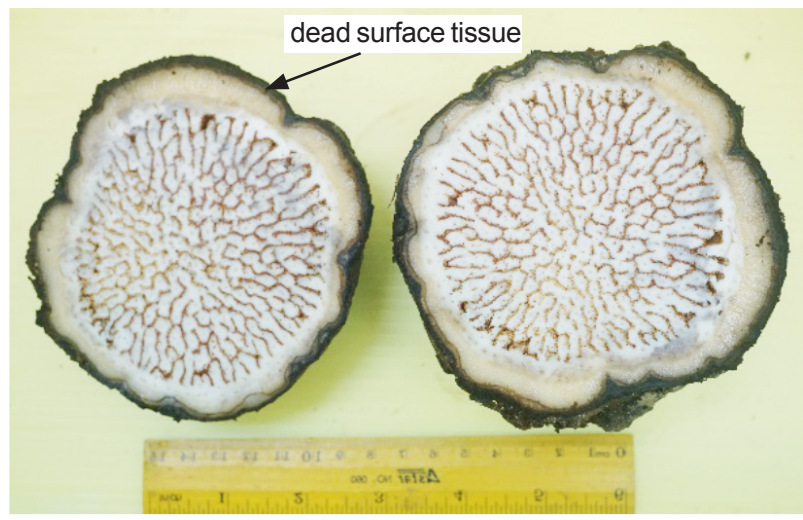

Figure 13 Young fruit in t.s. showing labyrinth of placental partitions and surface of dead tissue

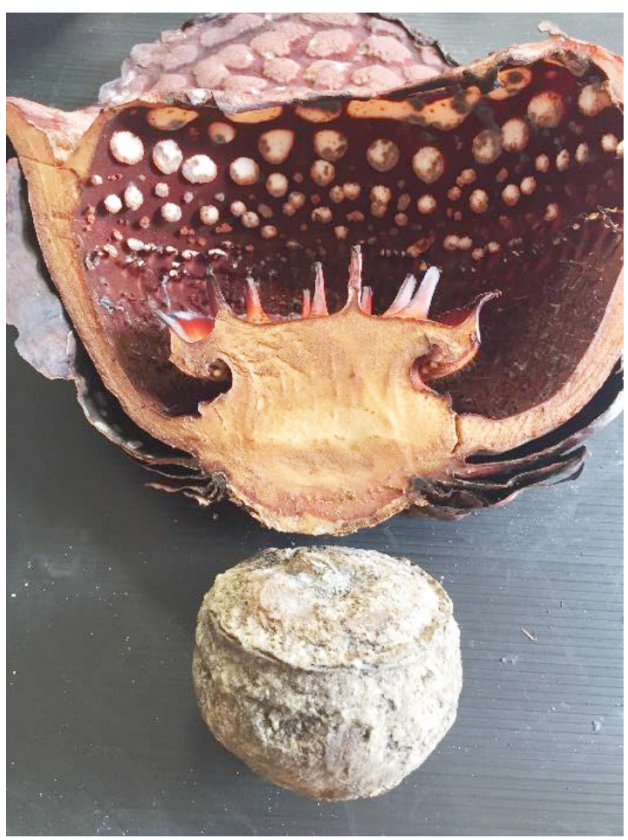

Figure 14 Comparison of central axis of flower (above) with mature fruit (below) 


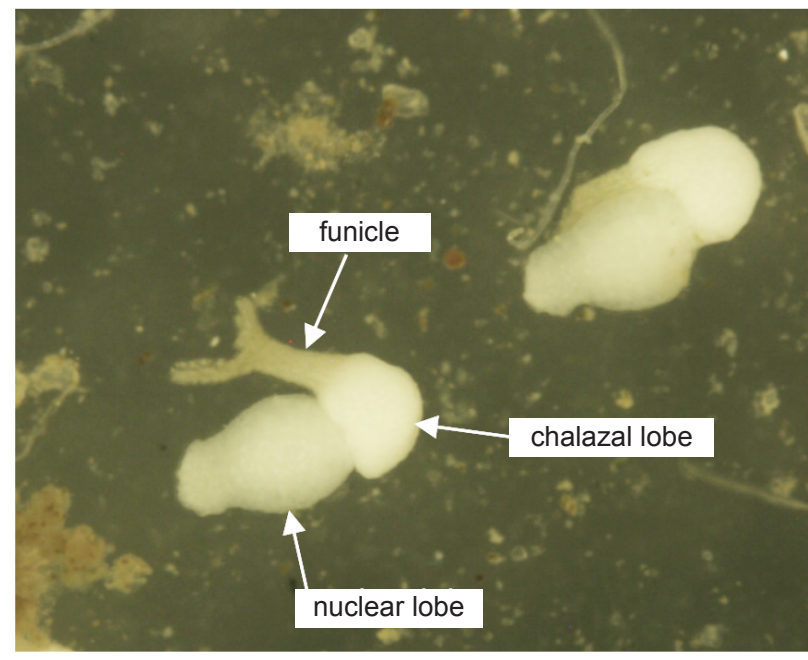

Figure 15 Isolated young seeds

is connected to the placenta by the funicle, is here called the chalazal lobe. The distal lobe containing what Brown called a 'nucleus' is here called the nuclear lobe, and the nucleus is called the Brownian nucleus.

Mature ovules are about $0.4 \mathrm{~mm}$ long at anthesis. The ripe fruit contains a mixture of small seeds about $0.4 \mathrm{~mm}$ long and large seeds about $0.9 \mathrm{~mm}$ long (Figure 16). Presumably the large seeds are fertilised seeds and the small ones are not, but they otherwise look similar. In normal angiosperms, the seed has one or two covering layers known as integuments, each integument two or more cells thick (Endress 2011), and the integuments maturing to form a seed coat incorporating the chalaza. The seeds of Rafflesia have inner and outer integuments and contain a one-layered endosperm surrounding a rudimentary embryo-according to Bouman and Meijer (1994). I have not been able to confirm such details. Instead, the seeds have an epidermis of large cells with tough durable cell walls (Figure 17). The outer walls of the epidermal cells are pulled inwards as the seed matures, giving the seed a sculpted appearance. The chalazal lobe remains prominent and internally its cells are thick walled like the epidermal cells. Within the nuclear lobe, the Brownian nucleus consists of about 40 thin-walled isodiametric cells bounded by a thin, translucent, stiff membrane.

It is not known how the seeds are dispersed nor how they infect the host. Germination has never been observed (Nais \& Wilcock 1999). The seeds do not germinate on soil, on moist paper, on discs of Tetrastigma stems, under aseptic conditions in tissue-culture media, or

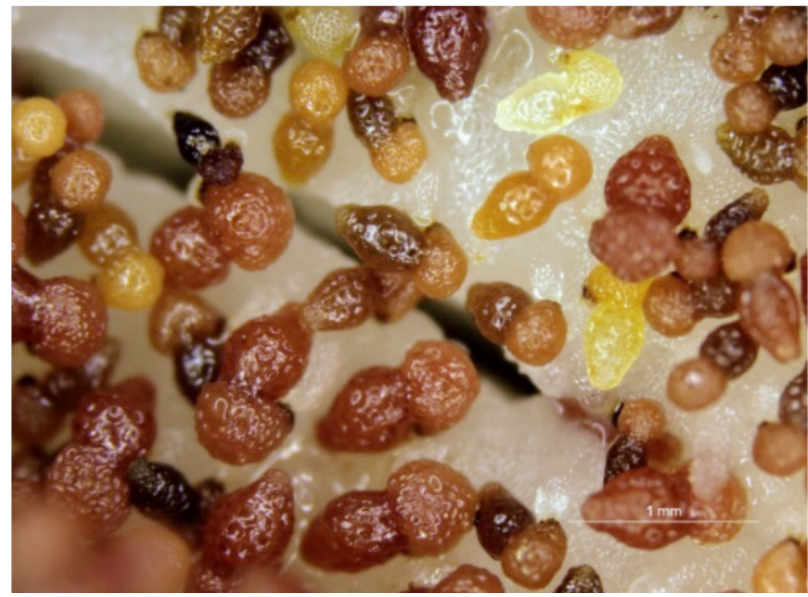

Figure 16 Seeds, small and large, in placental pulp

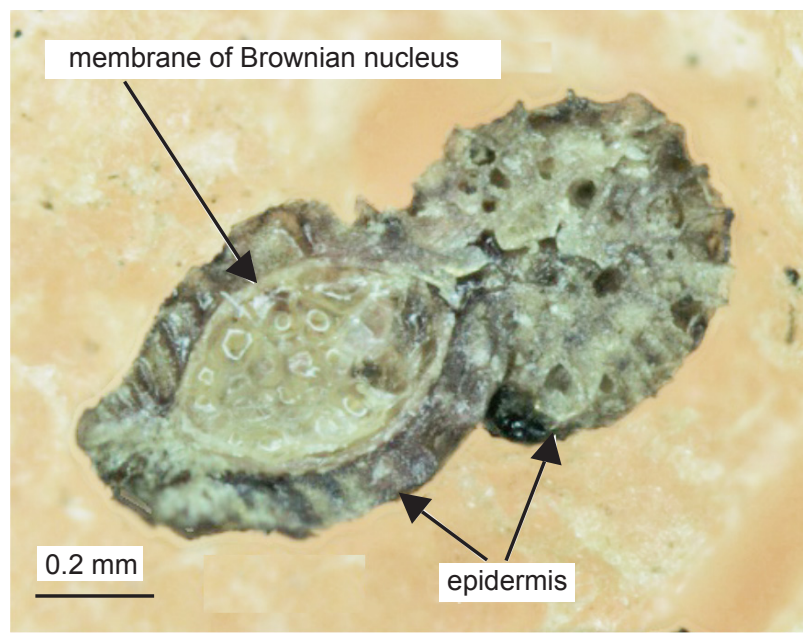

Figure 17 Mature seed in 1.s.

after passing through the digestive system of a tree shrew. Cutting off the beak of the Brownian lobe or the chalazal lobe to expose the Brownian nucleus also does not induce germination. Many more experiments are needed but it is difficult to obtain seeds for experiment because few buds develop into flowers and few flowers develop into fruits. If the seed germinates by producing a uniseriate filament, it would certainly not be an angiosperm seed and the seedling would not be an angiosperm seedling. The chalazal lobe is unique. Among herbaceous flowering plants the orchids produce the widest range of tiny seeds, ranging from 0.1 to $6 \mathrm{~mm}$ but none have a chalazal lobe (Barthlott et al. 2014).

Once exposed, the placental pulp to which the seeds are attached is quickly covered by fungal mycelia which grow over and destroy the seeds. However, if seeds are cleaned and dried before fungal infestation, they can be stored. In 
storage, the cells within the chalazal lobe dry up but the cells within the Brownian nucleus remain succulent for a few months. Perhaps seeds that escape fungal attack could lie dormant in the forest soil for months.

In my study of seeds and germination covering 600 woody species in 300 genera and 86 families (Ng 2014), I have never met anything like a Rafflesia seed in form or behaviour.

\section{The androecium}

The androecium consists of dome-shaped sessile stamens arranged evenly in a circle on the underside of the rim of the disk (Figure 5 and 18). These cannot be homologous with angiosperm stamens because the pollen is produced in multiple elongated cavities formed

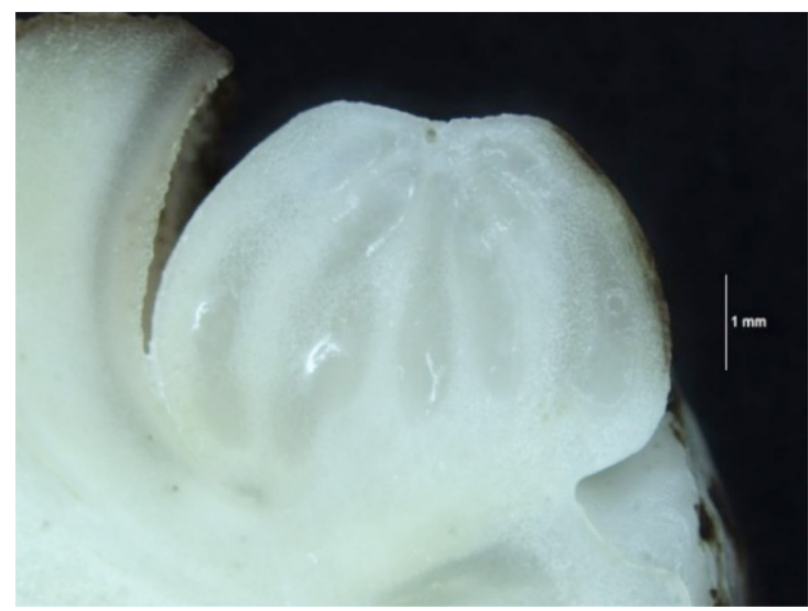

Figure 18 A stamen in side view

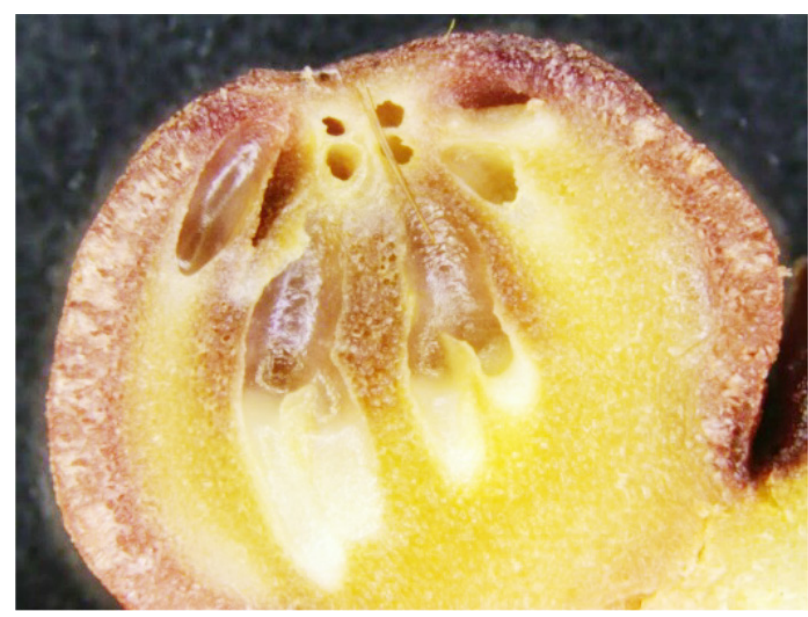

Figure 19 Oblique section of stamen showing pollen-bearing cavities converging at apex by fissure within solid tissue (Figures 19 and 20). The cavities may be branched once or twice, so the number of cavities seen in transverse section ranges from 20 to 40 depending on where the section is cut. Each stamen has a depression at its apex. The pollen-bearing cavities converge at the apex of the dome, where each cavity opens by a pore. The multiple pores are so closely clustered that they often merge into a single pore (Figure 21). The pores act as valves that are forced open when mature pollen is extruded. It is not known what generates the pressure to force the extrusion of the pollen.

The extruded pollen grains adhere to each other to form yellow hemispherical blobs at the points of extrusion but they are able to slide freely around each other so that surface tension makes each blob conform to a smooth

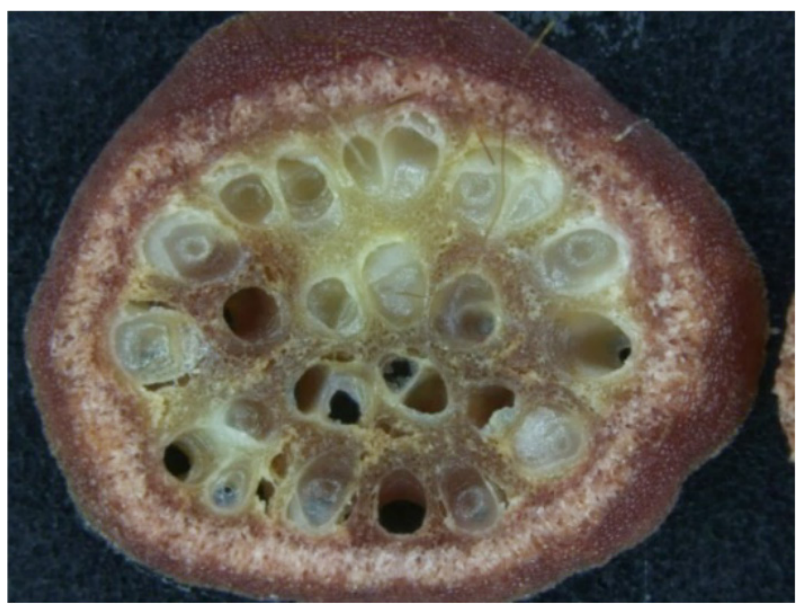

Figure 20 Stamen in t.s. showing pollen-bearing cavities, some with pollen, others emptied

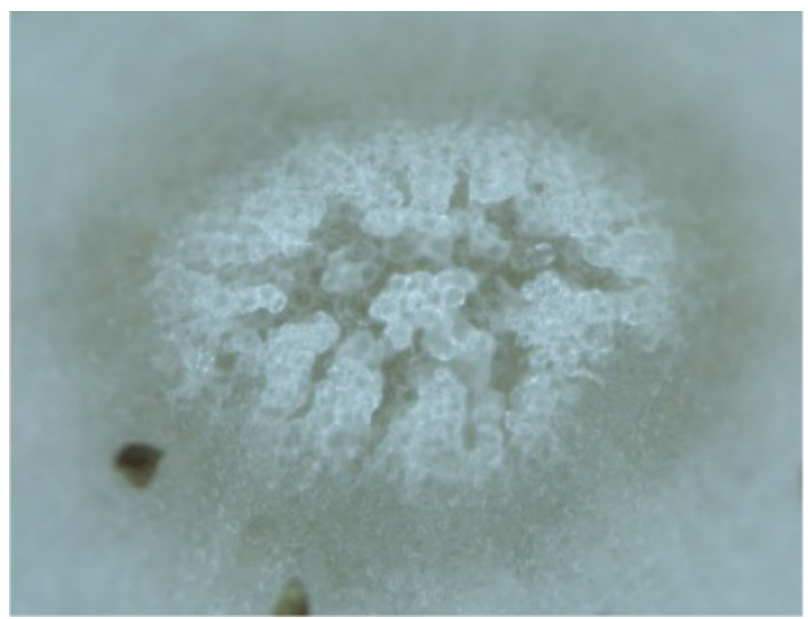

Figure 21 Apical compound pore of a stamen formed from union of multiple pores 
hemispherical shape (Figure 22). Pollen grains measure less than $20 \mu \mathrm{m}$ in diameter and each blob contains many thousands of pollen grains. Hence, the pollen payload carried by a pollencarrier is extremely high. When a drop of water is placed in contact with a blob of pollen on a glass slide, the pollen blobs dissociate into separate grains (Figure 23). The grains are polygonal due to mutual pressure when in a blob, but when isolated they are spherical. They sink in water.

\section{The genus Rafflesia}

The species of Rafflesia differ from each other mainly in quantitative parameters, summarised in Table 1. Rafflesia cantleyi is quite representative of the genus.

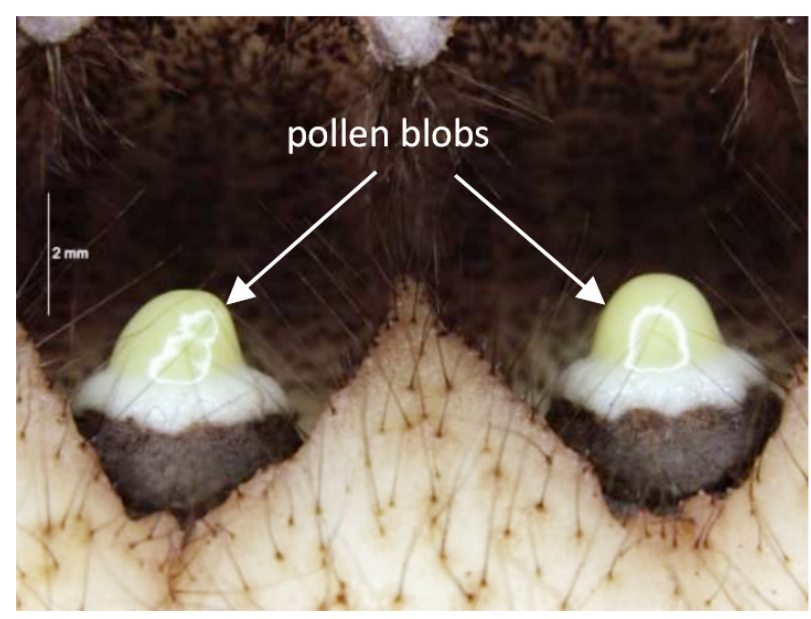

Figure 22 Extruded pollen blobs
The flower is ornamented by white wart-like epidermal outgrowths (Figures 1-2) of various sizes and configurations ranging from small dots to round patches to bands formed by merger of the patches. These patterns are used in species delimitation, supplemented by the form and distribution of branched hairs (ramenta) on the inner surface of the perianth tube extending up to the corona where they are replaced by luminous white pads of tissue (Figures 2, 24 and 25).

\section{The family Rafflesiaceae}

The family Rafflesiaceae consists of three genera, Rafflesia, Sapria and Rhizanthes. Sapria is close enough to pass for a Rafflesia. Rhizanthes looks

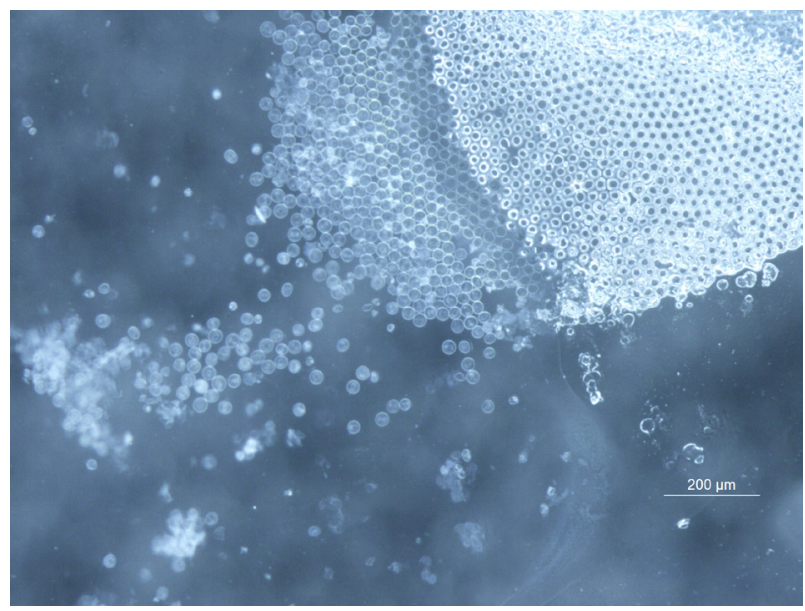

Figure 23 Pollen grains dissociating in water from a pollen blob

Table 1 Range of variation of various parameters in Rafflesia

\begin{tabular}{|c|c|}
\hline Maximum diameter of the shoot ball & $\begin{array}{l}8 \mathrm{~cm}(R . \text { manillana) to } 30 \mathrm{~cm}(R . \text { arnoldii) (Meijer 1997); } 13-15 \mathrm{~cm} \text { in } R \text {. } \\
\text { cantleyi }\end{array}$ \\
\hline $\begin{array}{l}\text { Maximum diameter of the open } \\
\text { flower }\end{array}$ & $\begin{array}{l}15-20 \mathrm{~cm} \text { in } R \text {. manillana to } 100 \mathrm{~cm} \text { in } R \text {. arnoldii (Meijer 1997); } 30-55 \mathrm{~cm} \text { in } \\
\text { R. cantleyi }\end{array}$ \\
\hline $\begin{array}{l}\text { Length of time for the shoot ball to } \\
\text { reach maximum size }\end{array}$ & $\begin{array}{l}13-17 \text { months in } R \text {. keithii, } 13-16 \text { months in } R \text {. pricei and } 10-14 \text { months in } R \text {. } \\
\text { tengku-adlinii (Nais 2001); } 40-50 \text { days in } R \text {. azlanii (Fatimah \& Nor-Nafizah } \\
2016 \text { ) }\end{array}$ \\
\hline Number of ovules/seeds per fruit & 270,000 in R. keithii (Nais 2001) \\
\hline Ovule length at anthesis & $0.4 \mathrm{~mm}$ \\
\hline Maximum seed length & $0.8-0.9 \mathrm{~mm}$ \\
\hline $\begin{array}{l}\text { Length of time from anthesis to fruit } \\
\text { maturity }\end{array}$ & $\begin{array}{l}6-8 \text { months (Nais 2001) based on } R \text {. arnoldii, } R \text {. gadutensis, } R \text {. patma and } R \text {. } \\
\text { keithii }\end{array}$ \\
\hline Number of stamens & $10-15$ in $R$. manillana, 36-40 in $R$. arnoldii (Meijer 1997); 24-29 in $R$. cantleyi \\
\hline $\begin{array}{l}\text { Number of pollen-bearing cavities in } \\
\text { a stamen }\end{array}$ & $20-40$ \\
\hline Number of processes on disk & $0-8$ in $R$. rochussenii to $20-50$ in $R$. arnoldii (Meijer 1997); $17-24$ in $R$. cantleyi. \\
\hline
\end{tabular}




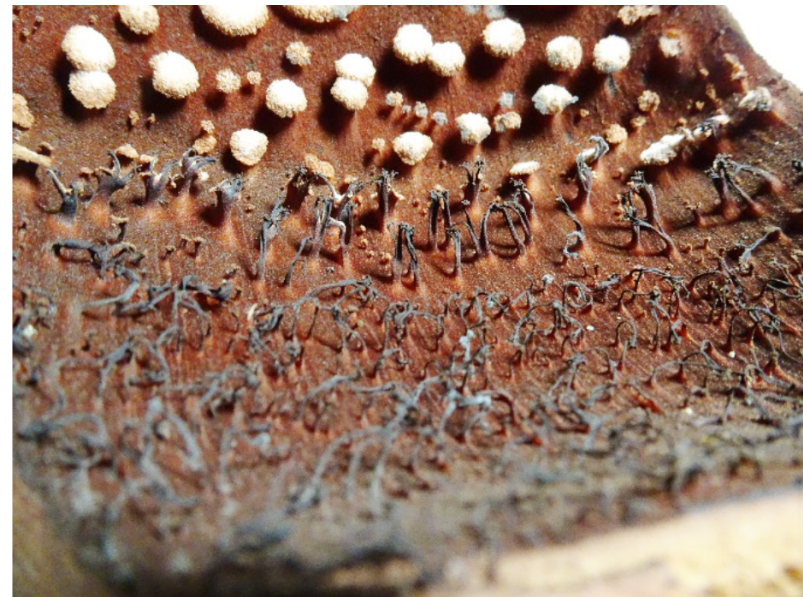

Figure 24 Transition of ramenta to luminous white pads

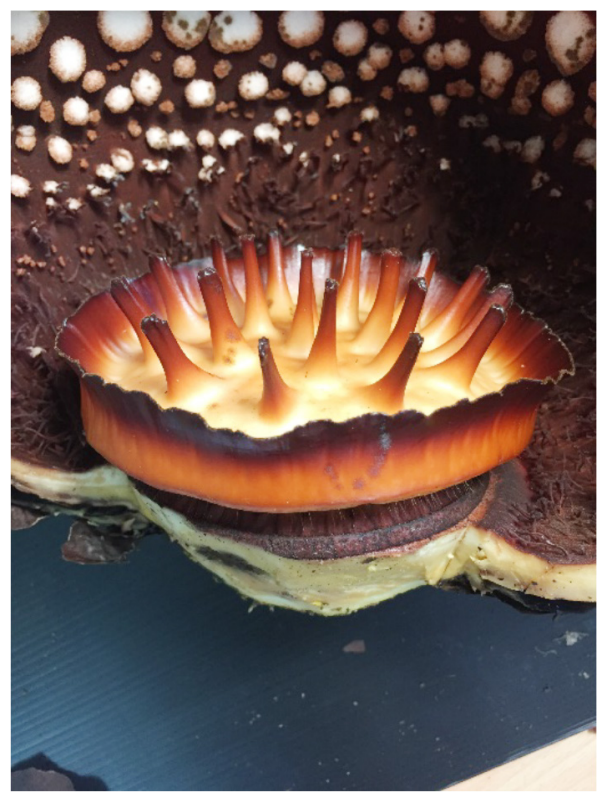

Figure 25 Luminous white pads on the corona in relation to the processes of the disk

quite different at first sight (Figure 26) but it conforms to the family in all significant details. The family characters are as listed below:

(1) Shoot developed precociously as a bud of many bracts overlapping a single flower. Number of bracts about 23 in Rafflesia, about 10 in Sapria (Nikolov et al. 2014), about 13 in Rhizanthes

(2) Perianth united into a tube at the base but divided distally into lobes-5 (rarely 10) lobes in Rafflesia), 10 in Sapria, about 16 in Rhizanthes

(3) Central axis of flower expanded apically to form a disk (Rafflesia), cup (Sapria) or bulb (Rhizanthes), bearing the stamens and stigma

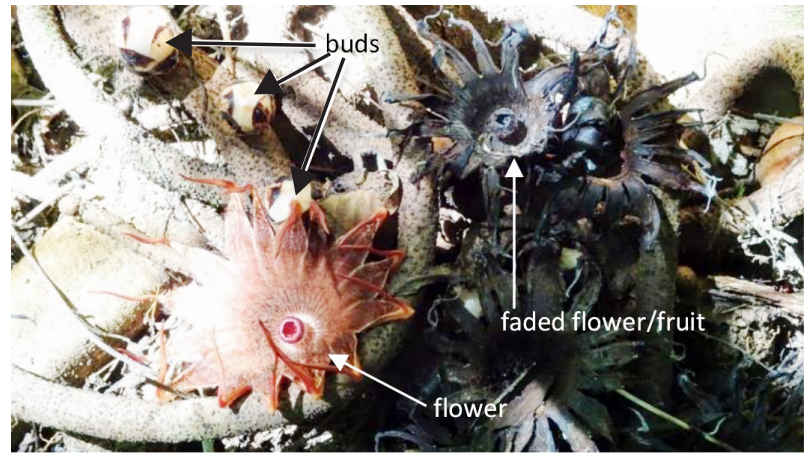

Figure 26 Cluster of Rhizanthes lowii flowers, buds and fruits at a natural site

(4) Gynoecium a non-carpellate, non-loculate cavity within the central axis that takes the form of a labyrinth of interconnected spaces and tightly spaced vertical anastomosing placental partitions

(5) Stigma in the form of a flat band of tissue, located on the expanded apical part of the central axis-under the rim of the disk (Rafflesia), on the outer surface of the cup (Sapria), and on the outer surface of the bulb (Rhizanthes)

(6) Androecium of sessile stamens, bearing pollen in cavities formed by fissure within solid tissue

(7) Pollen cavities in each stamen number 20-40 in Rafflesia, 2 in Sapria (Nikolov et al. 2014), and 2 (or perhaps 4) in Rhizanthes; the pollen extruded through pores

(8) Ovules/seeds bilobed with a prominent chalazal lobe

(9) Fruit size fixed at anthesis; in Rafflesia, most of flower decays leaving a layer of remnant tissue to form the wall of the globose fruit; in Rhizanthes, the flower hardens around the gynoecial cavity so the fruit looks like a dried flower and a fruit can only be distinguished from a faded male flower by dissecting to see if there are seeds or ovules in the gynoecial cavity

The genera Mitrastema, Cytinus, Apodanthes, Bdallophyton and Pilostylis have sometimes been included in Rafflesiaceae, but from published descriptions they are all undoubtedly angiosperms. In Mitrastema, for example, the perianth, stamens and pistil are clearly serial organs homologous with the corresponding structures in other angiosperms. The pistil bears a stigma at its apex and a swollen ovary at its base. 


\section{DISCUSSION}

The history of Rafflesia has been one of morphological misinterpretation and taxonomic denial. Rafflesia was, by its magnificent flowers, instantly locked into the Angiospermae. The absence of carpels was not recognised. The form and location of the stigma is so unlike any angiosperm that it took over 50 years to locate it and another 100 years to work out a plausible mechanism of pollination. Brown (1821, 1834) struggled over whether the ovary was inferior or superior and could not explain the placentation. The lack of homology between Rafflesia stamens and those of angiosperms greatly troubled Brown. He offered three interpretations to explain how the stamen could be related to other angiosperm stamens but he himself was not convinced by any of them. Brown (1834) had a fruit illustrated in detail showing its pattern of deep surface fissures, but did not try to explain its peculiar appearance. We know now that the pattern would vary from fruit to fruit because it results from the drying and shrinkage of originally succulent tissue and the weathering of the semi-woody remains. Brown's successors in plant taxonomy simply ignored Brown's misgivings.

The true nature of the fruit as a post-anthesis flower without a true pericarp has been ignored. Meijer (1997) described the fruit of Rafflesia as berry-like and made no attempt to describe the fruit of Rhizanthes, merely stating that it is 'hidden under dried-out flowers'. Banziger and Hansen (2000) described the fruit of Rhizanthes as 'globose, at maturity blackish, with traces of attachment of column, tepals, scales'. I have not found any description of the fruit of Sapria. The main features that separate Rafflesia and its family from mainstream flowering plants are listed in Table 2.

Angiosperms are defined by their ovules and seeds contained in ovaries formed by carpels, while gymnosperms are defined by their ovules and seeds on open carpel surfaces. Rafflesia, having no carpels, is neither angiosperm nor gymnosperm. The lack of carpels is not a morphological quirk with little taxonomic significance (like the absence of cotyledons in some angiosperm seedlings) but part of what looks like a total difference in plant design, covering not only the gynoecium but also the androecium, fruits and seeds.

Through genomic analysis, Rafflesia has been placed close to or within the family Euphorbiaceae (Wurdack \& Davis 2009, Nikolov \& Davis 2017). The gigantic size of flowers of Rafflesia compared with the small size of flowers that characterise the Euphorbiaceae has been attributed to a high rate of evolution of floral size (Davis 2008), but if Rafflesia has indeed evolved from the Euphorbiaceae it would have had to evolve rapidly not only its flower size, but also a whole set of fundamental qualitative features to replace angiosperm carpels, stamens, fruits, and

Table 2 How Rafflesia (and Rafflesiaceae) differs from mainstream flowering plants

\begin{tabular}{|c|c|c|}
\hline Organ & Mainstream flowering plants & Rafflesia/Rafflesiaceae \\
\hline Gynoecium & $\begin{array}{l}\text { Ovules develop within a uni- or multiloculate } \\
\text { carpellate organ at the apex of the flower, with } \\
\text { stigmas at the apices of the pistils/carpels }\end{array}$ & $\begin{array}{l}\text { Ovules develop in a non-carpellate cavity within the } \\
\text { central axis of the flower, with stigma in the form of } \\
\text { a circular band on the upper part of the central axis } \\
\text { of the flower }\end{array}$ \\
\hline Fruit & $\begin{array}{l}\text { Formed by enlargement of the ovary after } \\
\text { flowering }\end{array}$ & $\begin{array}{l}\text { Fixed by the remnants of the flower around the } \\
\text { gynoecial cavity }\end{array}$ \\
\hline Ovule & $\begin{array}{l}\text { An unlobed (unilobed) structure covered by } \\
\text { integuments; chalaza merged with integuments } \\
\text { into testa of the seed }\end{array}$ & $\begin{array}{l}\text { Bilobed structure covered by an epidermis of large } \\
\text { cells; with persistent chalazal lobe }\end{array}$ \\
\hline Seed & Containing an embryo & Without any recognisable embryo \\
\hline Stamen & $\begin{array}{l}\text { A leaf-homolog, with pollen contained in } \\
\text { bifacial anther sacs, opening in various ways to } \\
\text { release or expose pollen }\end{array}$ & $\begin{array}{l}\text { A dome-shaped structure (squeezed side-by-side in } \\
\text { Rhizanthes), with pollen in cavities formed by fissure, } \\
\text { extruding through pores }\end{array}$ \\
\hline $\begin{array}{l}\text { Shoot } \\
\text { system }\end{array}$ & $\begin{array}{l}\text { Shoot system indeterminate, with leafy parts } \\
\text { initiated in an apical meristem in acropetal } \\
\text { sequence }\end{array}$ & $\begin{array}{l}\text { Shoot system determinate, with all leafy parts } \\
\text { initiated simultaneously in bud at the start of shoot } \\
\text { development }\end{array}$ \\
\hline
\end{tabular}


seeds. The totality of morphological evidence indicates an alternative explanation, that Rafflesia and Rafflesiaceae belong to a lineage of flowering plants different from Angiospermae. My raising of this possibility has met with hostility and rejection by the journal that I originally sent this paper to, with comments that my observations are irrelevant.

The morphological peculiarities of Rafflesia have long been simmering but have been routinely 'explained' as adaptations to a parasitic lifestyle, of no taxonomic significance. This explanation, together with 'rapid evolution' blunts the cutting edge of scientific enquiry by trivialising the issues. Considering that a cube $100 \mathrm{~cm}$ long is $100^{3}$ or $1,000,000$ times larger by volume than a cube of $1 \mathrm{~cm}$ diameter, a Rafflesia flower of $100 \mathrm{~cm}$ diameter (as in $R$. arnoldii) compared with a 1-cm euphorb flower is no trivial difference. No other parasite produces such a monstrously large reproductive organ at the expense of its host. Description of the Rafflesia endophyte as slender uniseriate strands (Nikolov \& Davis 2017) or small clusters of cells (Sofi et al. 2019) only deepens the mystery of how a tiny endophytic structure can commandeer the host resources needed for the development of a massive flower. At the other end of the scale, Rafflesia produces some of the tiniest of seeds, in immense quantity-as many as a quarter of a million units per fruit, but no one has found a way to induce the seeds to germinate. It is a mystery how the seeds are dispersed and how they infect their hosts. It is a mystery why Rafflesia occurs in only small critically endangered patches whereas the host plants, of the genus Tetrastigma, are common and widespread in tropical SouthEast Asia.

Despite having attracted more attention than any other flower, Rafflesia remains supremely enigmatic. Molecular biology places Rafflesia within the ambit of Euphorbiaceae but this is contradicted by empirical, visible, tangible evidence from developmental morphology.

\section{ACKNOWLEDGEMENTS}

This study was sponsored by the Rafflesia Conservation and Interpretation Centre of the Forest Research Institute Malaysia (FRIM) in Gerik, Upper Perak. I am indebted to its manager, Noorsiha A for inviting me to make this study and to her staff: Nuranis-Suraya B, Nurul-
Huda AK, Nadiatul-Hiduyah ZA, Ishak Y and Mohamad-Shahmi D for keeping Rafflesia under close observation in the field and providing fresh materials for this study. I am grateful to SitiMunirah MY, Ong PT and Mohamad-Aidil N for microphotography support, and to Siti-Munirah MY and Latiff AM for discussions about Rafflesia and Tetrastigma and to Schlegel FM for help with the German literature.

\section{REFERENCES}

BANZigER H. 1991. Stench and fragrance: unique pollination lure of Thailand's largest flower, Rafflesia kerrii Meijer. Natural History Bulletin, Siam Society 19: 19-52.

Banziger H \& Hansen B. 2000. A new taxonomic revision of a deceptive flower, Rhizanthes dumortier (Rafflesiaceae). The Natural History Bulletin of the Siam Society 48: 117-143.

Barthlott W, Grosse-Veldmann B \& Korotkova N. 2014. Orchid Seed Diversity: A Scanning Electron Microscopy Survey. Englera 32. Botanical Garden and Botanical Museum, Berlin-Dahlem, Berlin.

Bouman F \& MejJer W. 1994 Comparative structure of ovules and seeds in Rafflesiaceae Plant Systematics and Evolution 193: 187-212.

BROwn R. 1821. An account of a new genus of plants, named Rafflesia. Transactions of the Linnean Society 13: 1-42.

BRown R. 1834. Description of the female flower and fruit of Rafflesia arnoldii with remarks on its affinities, and an illustration of the structure of Hydnora africana. Transactions of the Linnean Society of London 19: 221-239.

DAvis CC. 2008. Floral evolution: dramatic size change was recent and rapid in the world's largest flowers. Current Biology 18: R1102-R1104. https://doi.org/10.1016/j. cub.2008.10.011.

ENDRESS PK. 2011. Angiosperm ovules: diversity, development, evolution. Annals of Botany 107: 1465-1489.

FATIMAH M \& Nor-NAfizAH MNN. 2016. A preliminary note on the growth rate of male Rafflesia azlanii Latiff \& Wong Rafflesiaceae. Malayan Nature Journal 68: 1-5.

Goethe JW von. 1790. Versuch die Metamorphose der Pflanzen zu erklären. Ettinger, Gotha. Available in English as Metamorphosis of Plants. The MIT Press, Cambridge.

KoORdERS SH von. 1918. Botanisch Overzicht der Rafflesiaceae van Nederlandsch-Indië. Met Determinatie-Tabellen en Soortbeschrijvingen; Hoofdzakelijk Naar Solms-Laubach. Mededeeling No. 4. G Kolff \& Co., Batavia.

Meijer W. 1997. Rafflesiaceae. Flora Malesiana (Series 1) 13: $1-42$.

NaIs J. 2001. Rafflesia of The World. Natural History Publications Borneo Sdn. Bhd., Kota Kinabalu.

NAIS J \& Wilcock CC. 1999. The propagation of Rafflesia and its host plant: prospects for ex-situ conservation. Sabah Parks Nature Journal 2: 111-120.

NG FSP. 2014. Tropical Forest Fruits, Seeds, Seedlings and Trees. Forest Research Institute Malaysia, Kepong, Malaysia.

Nikolov LA, Staedler YM, Manikam S et al. 2014. Floral structure and development in Rafflesiaceae with emphasis on their exceptional gynoecia. American Journal of Botany 1012: 225-243. 
Nikolov LA \& Davis CC. 2017. The big, the bad, and the beautiful: biology of the world's largest flowers. Journal of Systematics and Evolution 55: 516-524.

Sofi M, Adhityo W \& da Silva JT. 2019. Development of the endophytic parasite, Rafflesia patma Blume, among host plant (Tetrastigma leucostaphylum (Dennst.) Alston) vascular cambium tissue. South African Journal of Botany 123. 382-386. http://dx.doi.org/10.1016/j. sajb.2019.03.028.
Solms-Laubach HG. 1876. Die entwickelung der blüthe bei Brugmansia zippelii $\mathrm{Bl}$. und Aristolochia clematitis L. Botanische Zeitung 31: 481-489.

WURDACK KJ \& DAVIS CC. 2009. Malpighiales phylogenetics: gaining ground on one of the most recalcitrant clades in the angiosperm tree of life. American Journal of Botany 96: 1551-1570. 